\title{
A new Eliomys from the Late Miocene of Spain, and its implications for the phylogeny of the genus
}

Samuel Mansino, Antonio García-Alix, Francisco J. Ruiz-Sánchez, and Plinio Montoya

Acta Palaeontologica Polonica 60 (3), 2015: 577-588 doi:http://dx.doi.org/10.4202/app.00014.2013

In this paper, we describe a previously unknown species of the glirid Eliomys from the Late Miocene and Early Pliocene Cabriel, Alcoy and Granada basins of southeastern Spain. Eliomys yevesi sp. nov. is characterized by its relative small size, narrow lingual wall and common presence of two centrolophs in the upper molars, and well-developed centrolophids in the lower molars. The new species is the probable ancestor of $E$. intermedius, which in turn represents the ancestor of the extant $E$. quercinus. According to its morphologic and biometric features, the origin of E. yevesi sp. nov. is likely to be found in some population of $E$. truci from the Late Miocene. Based on these affinities, we propose the lineage E. truci-E. yevesi sp. nov.-E. intermedius-E. quercinus, in which there is a trend towards the development of centrolophs, as well as the reduction of accessory crests.

Key words: Mammalia, Rodentia, Gliridae, Eliomys, Late Miocene, Spain.

Samuel Mansino [ㅎamuel.mansino@uv.es] and Plinio Montoya [plinio.montoya@uv.es], Departament de Geologia, Universitat de València, 46100 Burjassot, Spain; Antonio García-Alix [agalix@ugr.es], Instituto Andaluz de Ciencias de la Tierra (IACTCSIC-UGR), Consejo Superior de Investigaciones Científicas, Universidad de Granada, Avenida de las Palmeras no 418100 Armilla, Granada, Spain;

Francisco J. Ruiz-Sánchez [francisco.ruiz@uv.es], Departament de Geologia, Universitat de València, 46100 Burjassot, Spain; and Museu Valencià d'Història Natural, L'Hort de Feliu, P.O. Box 8460, Alginet, Valencia, 46018, Spain.

This is an open-access article distributed under the terms of the Creative Commons Attribution License (for details please see creativecommons.org), which permits unrestricted use, distribution, and reproduction in any medium, provided the original author and source are credited. 
Farf Full text $(535.2 \mathrm{kB})$ ।

POFF Supplementary file $(108.5 \mathrm{kB})$ 